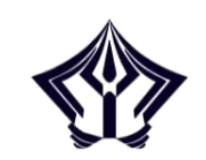

ANFUSINA: JOURNAL OF PSYCHOLOGY

http://ejournal.radenintan.ac.id/index.php/anfusina

DOI: //dx.doi.org/10.24042/ajp.v2i1.4155

Volume 2, Nomor 1, April Tahun 2019

\title{
Pola Penyesuaian Diri Mantan Anggota Gafatar Pasca Pemulangan Ke Daerah Asal
}

\author{
Achmad Irfan Muzni \\ Universitas Muhammadiyah Metro \\ irf_2007@yahoo.com \\ Dwi Redjeki Endang Haniwati \\ Universitas Muhammadiyah Gresik \\ haniwati@gmail.com
}

\begin{abstract}
The arson expulsion experienced by a former Gafatar member in Mempawah, West Kalimantan led the government to take steps by returning former Gafatar members to their respective areas of origin. On the other hand, the Majelis Ulama Indonesia (MUI) officially declared that Gafatar was a cult. Both of these can create resistance from the surrounding community when former Gafatar members return to their respective regions of origin. This is a challenge for former Gafatar members to be able to adjust to their environment. This study aims to determine the pattern of adjustment of former Gafatar members after repatriation to the area of origin. Using a type of qualitative descriptive research. Data retrieval method using observation and interviews in-depth research subjects and other individuals around them. The research subjects were 3 people. The analytical method used is descriptive qualitative analysis, namely by giving a review or interpretation of the data obtained so that it becomes more clear and meaningful. From the data analysis it was found that in adjusting, former Gafatar members tended to be more selective in choosing the topic of conversation with the surrounding community, trying to think from the perspective of others, trying to provide an alternative perspective on their environment, following what their environment wants, be more careful in
\end{abstract}


interacting, tend to ignore negative responses from the environment, and stay in touch with other former Gafatar members.

\begin{abstract}
Abstrak
Peristiwa pengusiran dengan pembakaran yang dialami oleh mantan anggota gafatar di Mempawah, Kalimantan Barat membuat pemerintah mengambil langkah dengan mengembalikan mantan anggota gafatar ke daerah asal masingmasing. Di sisi lain, Majelis Ulama Indonesia (MUI) secara resmi menyatakan bahwa Gafatar merupakan aliran sesat. Kedua hal tersebut dapat memunculkan resistensi dari masyarakat sekitar saat mantan anggota Gafatar kembali ke daerah asal masing-masing. Hal itu menjadi tantangan tersendiri bagi mantan anggota Gafatar untuk dapat menyesuaikan diri dengan lingkungannya. Penelitian ini bertujuan untuk mengetahui pola penyesuaian diri mantan anggota gafatar pasca pemulangan ke daerah asal. Penelitian ini menggunakan jenis penelitian deskritif kualitatif. Metode pengambilan data dengan menggunakan observasi dan wawancara mendalam subyek penelitian dan individu lain yang ada disekitarnya. Subyek penelitian berjumlah 3 orang. Metode analisa yang digunakan adalah analisis deskriptif kualitatif yaitu dengan memberikan ulasan atau interpretasi terhadap data yang diperoleh sehingga menjadi lebih jelas dan bermakna. Dari analisis data didapatkan bahwa dalam menyesuaikan diri, mantan anggota gafatar cenderung lebih selektif dalam memilih topik pembicaraan dengan masyarakat di sekitarnya, mencoba berpikir dari sudut pandang orang lain, berusaha memberikan alternatif cara pandang kepada lingkungannya dalam melihat dirinya, mengikuti apa yang dikehendaki oleh lingkungannya, lebih berhati-hati dalam berinteraksi, cenderung mengabaikan respon negatif dari lingkungan, serta tetap berhubungan dengan mantan anggota gafatar lainnya.
\end{abstract}

Keyword: Pattern of Self-Adjustment, Former Gafatar Member.

\title{
Pendahuluan
}

Awal tahun 2016 masyarakat Indonesia disuguhkan pemberitaan yang marak tentang organisasi masyarakat Gerakan Fajar Nusantara (Gafatar). Pemberitaan mengenai Gafatar sendiri mulai heboh semenjak hilangnya dokter asal Lampung, Rica Tri Handayani, bersama anak balitanya yang bernama Zafran Ali Wicaksono, sejak 30 Desember 2015 di Yogyakarta. Dokter Rica bersama anaknya akhirnya ditemukan oleh pihak berwajib di Pangkalan Bun, Kalimantan Tengah (10/1/2016) lalu. Kepergian dokter Rica ke Pangkalan Bun ini disinyalir berkaitan dengan Gafatar ("Psikolog Tika Bisono: Gafatar Adalah Fenomena Lama," 2016). 
Gerakan Fajar Nusantara (Gafatar) adalah organisasi kemasyarakatan yang berdiri di Jakarta pada tanggal 14 Agustus 2011 dan diketuai oleh Mahful M. Tumanurung. Ormas ini mengklaim dirinya sebagai organisasi yang bergerak dalam bidang sosial budaya yang bertujuan membangkitkan kembali kejayaan bangsa Nusantara menjadi mercusuar dunia ("Apa itu Gerakan Fajar Nusantara (Gafatar)," 2015).

Namun berbagai kalangan mensinyalir Gafatar merupakan metamorfosis dari Al-Qiyadah Al-Islamiyah, sebuah aliran kepercayaan yang melakukan sinkritisme ajaran dari Alquran, Injil, Yahudi, dan wahyu yang diakui turun dari pemimpinnya. Aliran ini dipimpin Ahmad Musadeq yang mengaku dirinya sebagai nabi. Hal itu menjadi salah satu dasar bagi Majelis Ulama Indonesia (MUI) mengeluarkan fatwa bahwa Gafatar merupakan aliran sesat dan menyesatkan ("Majelis Ulama Indonesia (MUI) Pusat mengeluarkan fatwa sesat bagi organisasi Gerakan Fajar Nusantara (Gafatar)," 2016).

Sebelum MUI menyampaikan fatwanya secara resmi, beberapa ulama sudah menyatakan bahwa gafatar adalah sesat. Hal ini pula yang mendasari Gafatar akhirnya membubarkan diri, sebagaimana yang dinyatakan mantan Ketua DPD Gafatar Yogyakarta bahwa organisasi Gafatar pusat sudah bubar sejak 2015 karena dianggap sesat oleh ulama ("Gafatar Sudah Bubar sejak 2015," 2016). Sumber lain menyatakan bahwa Gafatar membubarkan diri pada 13 Agustus 2015 melalui kongres luar biasa ("Mantan Ketum Gafatar Akui, Kalimantan Daerah Tujuan Pertanian," 2016).

Sebelumnya, Gafatar di daerah Kalimantan Tengah dan Kalimantan Barat telah membubarkan diri tanggal 27 April 2015. Pembubaran diri dilakukan karena banyaknya opini yang buruk tentang organisasi tersebut ("Tak Tahan Opini Publik Yang Buruk, Ormas Gafatar Nyatakan Diri Bubar,” 2015).

Meskipun sudah membubarkan diri, mantan anggota gafatar masih ingin melaksanakan program utama gafatar yakni pertanian mandiri dengan membentuk kelompok tani manunggal sejati. Untuk melaksanakan program ini, daerah Kalimantan dijadikan pilot project. Karena itu mantan anggota Gafatar secara berangsur eksodus ke daerah Kalimantan, salah satunya adalah Mempawah, Kalimantan Barat ("Mantan Ketum Gafatar Akui, Kalimantan Daerah Tujuan Pertanian," 2016). 
Kehadiran mantan anggota gafatar ini menimbulkan reaksi dari masyarakat sekitar. Warga ketakutan jika keberadaan mantan anggota Gafatar akan dapat mempengaruhi keyakinan mereka. Ribuan warga akhirnya melakukan pengusiran dengan menyerang permukiman mantan anggota Gafatar di Desa Moton, Kecamatan Mempawah Timur, Kabupaten Mempawah, Kalimantan Barat. Massa membakar 10 rumah yang dihuni 749 orang ("Ribuan Warga Bakar Permukiman Gafatar di Kalimantan Barat," 2016).

Peristiwa tersebut membuat mantan anggota gafatar dievakuasi dan dipulangkan ke daerah asal masing-masing. Pemulangan ini difasilitasi oleh pemerintah. Sebelum dipulangkan ke kampung halamannya, mantan anggota gafatar ini dikumpulkan di shelter / penampungan pada masing-masing daerah asal untuk diberi pembekalan.

Di Kabupaten Gresik, mantan anggota gafatar yang dipulangkan tercatat berjumlah 61 orang yang berasal dari Kecamatan Gresik, Kebomas, Panceng, Balong panggang, Duduk sampeyan, dan Driyorejo.

Secara bertahap, mantan anggota gafatar ini dipulangkan setelah mendapat pembekalan dari Pemerintah Kabupaten. Pembekalan ini dimaksudkan agar mereka dapat kembali ke kampung halamannya dengan tenang dan tanpa menimbulkan gejolak di lingkungannya. Dengan kata lain, mereka diharapkan dapat menyesuaikan diri terhadap lingkungannya dengan baik.

Kartono (2000), menyebutkan bahwa penyesuaian diri adalah usaha manusia untuk mencapai harmoni pada diri sendiri dan pada lingkungan, sehingga rasa permusuhan, dengki, iri hati, prasangka, depresi, kemarahan dan lain-lain emosi negatif sebagai respon pribadi yang tidak sesuai dan kurang efisien bisa dikikis habis.

Namun demikian, peristiwa pengusiran dengan pembakaran yang dialami masih menyisakan pertanyaan yang tak terjawab, sekaligus kekecewaan yang cukup dalam bagi mereka. Selain itu, adanya fatwa gafatar adalah aliran sesat berpotensi menjadi persoalan tersendiri bagi mereka dalam menjalani kehidupan di lingkungannya. Meskipun MUI menyatakan bahwa mantan anggota gafatar wajib dilindungi, namun masyarakat cenderung memberikan label negatif terhadap mereka.

Pemberian label negatif ini dapat berakibat negatif pada mereka. Menurut Ganengwin (2007), label negatif merupakan pemberian cap atau label yang mempunyai makna negatif sehingga cenderung akan memberikan dampak negatif bagi individu yang 
diberi label. Dampak negatif yang dapat muncul adalah menarik diri dari lingkungannya atau bahkan dikucilkan.

Beberapa hal tersebut menjadi tantangan tersendiri bagi mantan anggota gafatar dalam proses penyesuaian diri dengan lingkungan sekitarnya.

Penyesuaian diri merupakan suatu konstruksi/bangunan psikologi yang luas dan komplek, serta melibatkan semua reaksi individu terhadap tuntutan baik dari lingkungan luar maupun dari dalam diri individu itu sendiri. Dengan perkataan lain, masalah penyesuaian diri menyangkut aspek kepribadian individu dalam interaksinya dengan lingkungan dalam dan luar dirinya (Desmita, 2009).

Calhoun dan Acocella (1995), menyatakan bahwa penyesuaian diri dapat didefinisikan sebagai interaksi individu yang kontinu dengan diri individu sendiri, dengan orang lain, dan dengan dunia individu. Ketiga faktor tersebut secara konstan mempengaruhi individu dan hubungan tersebut bersifat timbal balik mengingat individu secara konstan juga mempengaruhi kedua faktor yang lain.

Sedangkan Kartono (2000), menyebutkan bahwa penyesuaian diri adalah usaha manusia untuk mencapai harmoni pada diri sendiri dan pada lingkungan, sehingga rasa permusuhan, dengki, iri hati, prasangka, depresi, kemarahan dan lain-lain emosi negatif sebagai respon pribadi yang tidak sesuai dan kurang efisien bisa dikikis habis.

Dari berbagai pandangan di atas dapat dirumuskan bahwa penyesuaian diri yang dimaksud dalam penelitian ini adalah interaksi individu yang kontinu dengan diri sendiri, orang lain dan lingkungan yang mencakup respon mental dan tingkah laku dalam mengatasi kebutuhan-kebutuhan dalam dirinya, ketegangan-ketegangan, konflikkonflik, dan frustrasi yang dialaminya, sehingga terwujud tingkat keselarasan atau harmoni antara tuntutan dari dalam diri dengan apa yang diharapkan oleh lingkungan dimana ia tinggal.

\section{Metode Penelitian}

Jenis penelitian ini adalah penelitian deskriptif kualitatif, yakni prosedur yang menghasilkan data deskriptif (Furchan, 1992). Bogdan dan Taylor (dalam Moleong, 2005) mendefinisikan data deskriptif berupa kata-kata tertulis lisan dari orang-orang dan perilaku yang diamati. Penelitian ini menggunakan metode wawancara dan observasi. Data yang dibutuhkan adalah data primer. Data primer meliputi wawancara tentang pandangan mantan anggota gafatar mengenai perlakuan resisten yang diterima dan bagaimana mengatasi 
resistensi yang diterima dari lingkungannya serta bagaimana penyesuaian diri yang dilakukan. Observasi yang dilakukan untuk melihat secara nyata perilaku penyesuaian diri mantan anggota gafatar di lingkungannya. Sedangkan indepth interview dilakukan untuk mengeksplorasi bagaimana pola penyesuaian diri yang dikembangkan mantan anggota gafatar di lingkungannya.

Subyek yang diteliti adalah sebanyak 3 orang mantan anggota gafatar yang kembali ke kampung halamannya. Adapun fokus penelitian ini difokuskan pada pemetaan pola/bentuk penyesuaian diri mantan anggota gafatar di lingkungannya.

Pengambilan data dilakukan dengan cara observasi dan Indepth Interview. Metode analisa yang digunakan adalah analisis deskriptif kualitatif yaitu dengan memberikan ulasan atau interpretasi terhadap data yang diperoleh sehingga menjadi lebih jelas dan bermakna. Menurut Miles dan Huberman (1992) bahwa dalam konteks analisa data pada tahapan yang dilakukan dimulai dari pengumpulan data, reduksi data, penyajian data, dan kesimpulan-kesimpulan dari data kemudian penarikan kesimpulan dan verifikasi data.

\section{Hasil Dan Pembahasan}

\section{- $\quad$ Subyek Pertama (MH)}

Subyek pertama berinisial MH berjenis kelamin laki-laki, usia 35 tahun dengan seorang istri dan 3 orang anak. MH dipulangkan ke kediaman orang tuanya di Desa Dalegan Kec. Panceng Kabupaten Gresik. Kepulangannya ke kediaman orang tua karena subyek belum memiliki rumah sendiri.

Subyek berpendidikan S-1 demikian juga istrinya. Sejak kuliah subyek mengaku sudah senang merantau. Sehingga subyek selama ini tidak berpikir untuk membangun rumah di kampung halamannya. Subyek mengaku sudah 6 tahun di perantauan dan sudah berpindah dua kali. Awalnya subyek merantau di Sulawesi Tenggara selama 4 tahun, kemudian pindah ke Kalimantan Selatan.

Hingga dirinya dipulangkan dari Kalimantan Selatan tempat dia merantau, Subyek meninggalkan aset berupa lahan pertanian yang dibeli secara berkelompok, alat-alat pertanian dan pertukangan, gerobak, serta sepeda motor. Semua aset yang ditinggalkan dititipkan kepada tetangga di Kalimantan Selatan. 
Subyek menyatakan dirinya belum bisa memahami kenapa harus dipulangkan dari perantauan. Seringkali subyek menyampaikan bahwa apa yang dilakukan bersama kelompoknya adalah bentuk pilihan hidup yang tidak melanggar berbagai ketentuan dalam bermasyarakat maupun berbangsa dan bernegara. Apa yang sudah dilakukan di Kalimantan justru dapat dikategorikan sebagai usaha membantu pemerintah dalam kedaulatan pangan. Apalagi tempat subyek tinggal di Banjarmasin Kalimantan Selatan tidak ada masalah. Pembakaran dan pengusiran hanya terjadi di Mempawah, Kalimantan Barat. Karena itu subyek tidak mengetahui detail peristiwa yang terjadi. Subyek hanya tahu bahwa dia dan komunitasnya dipulangkan ke daerah asal.

Namun demikian, subyek menyatakan bahwa sebagai warga negara akan patuh dengan kemauan pemerintah. Maka kepulangan dari tanah rantau diakui sebagai satu bentuk kepatuhan mereka terhadap aturan (keinginan pemerintah untuk memulangkan ke kampung halaman). Meskipun kepulangannya ke kampung halaman justru menimbulkan masalah baru bagi dirinya dan keluarganya. Masalah yang dimaksudkan oleh subyek bukan hanya tentang kekhawatiran ketidakjelasan keberadaan dan keberfungsian aset yang ditinggalkan di Kalimantan saja, melainkan juga tentang tempat tinggal, pekerjaan, dan sekolah untuk anak-anaknya di kampung halaman. Selain itu, Subyek juga menyatakan menghadapi stigma negatif sebagai dampak dari fatwa MUI yang menyatakan bahwa Gafatar merupakan aliran sesat dan menyesatkan.

a. Bentuk resistensi yang diterima dari lingkungan

Menjelang pemulangan ke kampung halaman, Subyek beserta keluarga sempat merasa khawatir tentang reaksi lingkungannya mengingat gencarnya pemberitaan tentang fenomena Gafatar. Subyek dan keluarga merasa khawatir jika mereka tidak diterima oleh masyarakat di kampung halamannya. Namun berbagai pihak, terutama pemerintah, selalu meyakinkan Subyek dan keluarga bahwa masyarakat di lingkungannya siap menerima mereka kembali.

Hari-hari pertama di kampung halaman, subyek agak canggung untuk bersosialisasi. Subyek masih belum dapat menghapus persepsi bahwa masyarakat kurang terbuka terhadap dirinya. Subyek mempersepsikan itu berdasar bahasa tubuh yang disampaikan masyarakat di sekitarnya. 
Beberapa bahasa tubuh yang dianggap isyarat oleh subyek sebagai tanda kurang terbuka adalah beberapa tetangga sering curicuri pandang atau melirik ketika subyek lewat di depan rumahnya. Perilaku itu mengesankan kecurigaan pada diri subyek. Hal itu juga dianggap subyek sebagai perilaku yang tidak biasa sebagaimana sebelum dirinya berangkat merantau.

Selain itu, dalam pergaulan, subyek merasa masyarakat masih canggung dengan dirinya, hal ini didasarkan atas perilaku yang terkesan lebih serius kepada subyek. Orang-orang di lingkungannya terkesan berhubungan dengan dirinya secara formal, tidak santai sebagaimana layaknya dengan teman atau tetangga seperti dulu lagi.

Sementara itu, masyarakat di lingkungannya menyatakan bahwa interaksi yang dilakukan dengan subyek memang dirasakan tidak sama seperti dulu lagi. Beberapa teman subyek menolak jika dikatakan mereka resisten terhadap subyek. Mereka menyatakan menerima kehadiran subyek dan keluarganya, namun mereka juga mengakui bahwa masih ada kecurigaan terhadap subyek. Mereka masih memiliki kekhawatiran jika subyek menyebarkan atau mempengaruhi orang lain dengan ajaran-ajaran yang sudah difatwakan sesat oleh MUI itu. Kekhawatiran itu yang muncul dalam bentuk interaksi yang terkesan formal dan kurang intim.

b. Cara mengatasi resistensi yang diterima

Subyek menyadari bahwa dirinya dianggap sebagai orang yang bermasalah dengan keyakinannya. Bagi Subyek, persoalan keyakinan adalah hal yang tidak perlu diperdebatkan. Masing-masing orang memiliki keyakinannya sendiri-sendiri dan itu tidak perlu diributkan. Apa yang selama ini diyakini merupakan pilihan dirinya. Karena itu subyek merasa enggan membicarakan tentang keyakinannya.

Di lingkungannya, subyek lebih selektif dalam memilih topik pembicaraan. Subyek cenderung menghindari pembicaraan dengan topik-topik keyakinan. Subyek lebih memilih pembicaraan dengan topik sehari-hari seperti bertani, berdagang, dan sejenisnya. Hal ini dimaksudkan sebagai usaha subyek untuk dapat berinteraksi lebih intim dengan lingkungannya.

Meskipun dirinya tidak dapat memungkiri rasa canggungnya dalam berinteraksi, namun subyek berusaha berpikir positif tentang perilaku teman dan tetangga yang dianggap resisten terhadap dirinya. Subyek selalu berusaha berpikir bahwa apa yang dilakukan teman dan 
tetangganya itu sebagai bentuk kewajaran karena hal itu sebagai akibat dari label sesat yang dilekatkan kepada kelompoknya.

Subyek juga selalu berusaha menetralisir dengan menjelaskan bahwa Gafatar sudah bubar sejak Agustus 2015. Apa yang dilakukan di perantauan bukan bentuk pengorganisasian ideologi, tetapi lebih kepada usaha untuk mencapai kedaulatan pangan dengan memanfaatkan lahan yang dianggap terlantar. Subyek bercerita tentang bagaimana mengolah lahan tidak produktif menjadi produktif, tentang penerimaan warga sekitar di perantauan, dan suasana yang tampak menyenangkan dan penuh harapan. Hal ini dilakukan sebagai bentuk penegasan bahwa dirinya bukan orang yang berbahaya bagi masyarakat di sekitarnya.

Selain itu, subyek juga masih berhubungan dengan mantan anggota Gafatar lainnya. Saling kontak ini dilakukan sebagai salah satu upaya saling menguatkan diantara mereka, mengingat persoalan yang dihadapi bukan hanya resistensi masyarakat, tetapi juga persoalan pekerjaan, sekolah bagi anak-anak mereka, dan aset yang hilang atau tertinggal.

\section{c. Pola penyesuaian diri}

Dari penjelasan di atas didapatkan beberapa hal yang dilakukan subyek dalam upaya penyesuaian diri adalah :

1. Selektif dalam memilih topik pembicaraan, yaitu menghindari pembicaraan dengan topik keagamaan. Hal ini dilakukan untuk menghindari adanya perbedaan pandangan dengan orang lain di lingkungannya, agar dirinya dapat membangun interaksi lebih intim dengan lingkungannya.

2. Mencoba berpikir dari sudut pandang orang lain, yaitu menganggap wajar jika beberapa orang di lingkungannya masih menaruh kecurigaan terhadap dirinya sebagai akibat dari fatwa sesat terhadap kelompoknya.

3. Menjelaskan tentang kondisi yang dialami dan berusaha memberikan alternatif cara pandang kepada lingkungannya dalam melihat dirinya.

4. Secara internal, subyek mencari dukungan psikologis dengan tetap berhubungan dengan mantan anggota gafatar lainnya.

\section{- $\quad$ Subyek Kedua (EFA)}

Subyek kedua berinisial EFA berjenis kelamin perempuan, berusia 37 tahun, status sebagai ibu rumah tangga dengan lima anak. 
Subyek bersama suami dan kelima anaknya berada di Mempawah, Kalimantan Barat selama tiga bulan. Setelah peristiwa pembakaran rumah hunian mantan anggota gafatar, Subyek beserta suami dan anak-anaknya dipulangkan ke kampung halamannya di Desa Tumapel Kec. Duduk Sampeyan Kabupaten Gresik. Subyek masih memiliki rumah di kampung halamannya.

Subyek menceritakan bahwa peran suaminya di Kalimantan sebagai tukang, karena memang profesinya ketika di Gresik juga sebagai tukang batu. Selama di Kalimantan, suaminya bertugas membuat rumah untuk anggota lain yang baru datang. Sementara dirinya berperan sebagai tukang memasak di dapur umum bersama ibu-ibu yang lain.

Meskipun baru tiga bulan subyek tinggal di Kalimantan, subyek mengaku sangat terkesan ketika hidup di sana. Hal-hal yang membuat subyek terkesan adalah cara hidup secara komunal yang dianggapnya sebagai bentuk kehidupan yang egaliter, penuh dengan suasana kekeluargaan dan gotong royong.

Subyek menyatakan bahwa apapun profesi seseorang, tidak ada yang lebih tinggi derajatnya. Hal ini ditunjukkan dengan apa yang dilakukan misalnya, seorang dokter, guru, petani, tukang, dan lainnya akan mendapat jatah yang sama. "Satu makan, ya semua makan, satu tidak makan ya tidak makan semua," jelas subyek.

Subyek menyampaikan bahwa mereka disatukan oleh cita-cita, yaitu mencapai kedaulatan pangan. Apa yang mereka lakukan sebenarnya menguntungkan pemerintah. Merubah lahan yang tidak tergarap menjadi produktif. Selain itu, masyarakat di sekitar perkampungan juga tampak senang dengan kehadiran mereka. Hal itu ditunjukkan dengan kegiatan sosial yang dilakukan bersama warga sekitar seperti bersih-bersih kampung, bahkan hasil pertanian seperti sayur-sayuran juga sebagian disumbangkan ke masyarakat sekitar.

Subyek juga menyampaikan keheranannya kenapa sampai terjadi pembakaran pemukiman yang dihuni. Bahkan dengan bernada protes, subyek menyampaikan bahwa mereka bukan teroris, tidak pernah berbuat onar, bahkan kegiatan yang dilakukan adalah bentuk aksi-aksi sosial, tapi kenapa dijelek-jelekkan. Subyek juga mencurigai bahwa pembakaran dan pengusiran yang terjadi memang dilakukan secara sengaja dan terencana.

a. Bentuk resistensi yang diterima dari lingkungan

Sebagaimana subyek pertama, subyek kedua juga merasa khawatir tentang reaksi lingkungannya jika ia dan keluarganya 
kembali ke kampung halaman mengingat gencarnya pemberitaan tentang fenomena Gafatar. Subyek dan keluarga merasa khawatir akan ditolak oleh masyarakat di kampung halamannya. Namun pemerintah desa dan tokoh masyarakat setempat menyatakan pada keluarga subyek bahwa masyarakat di lingkungannya siap menerima kehadiran mereka.

Sekembali di kampung halaman, masyarakat sekitar memang menerima kehadiran subyek dan keluarganya. Namun subyek menjelaskan bahwa penerimaan masyarakat sekitar seperti bersyarat. Subyek menyatakan masyarakat sekitarnya sulit menerima perbedaan. Sedangkan dirinya merasa berbeda dengan lingkungannya. Perbedaan dalam hal pola hidup dan keyakinan. Subyek merasa seakan-akan dirinya dituntut oleh lingkungan agar sama dengan mereka.

Tuntutan-tuntutan tersebut diwujudkan dalam bentuk ajakan dalam menjalankan tradisi-tradisi yang menurut masyarakat sekitarnya adalah tradisi Islami. Sementara subyek menyakini kegiatan itu lebih banyak disimpangkan dan justru tidak banyak memberikan manfaat. Jika subyek menyampaikan pandangannya yang berbeda, subyek akan dicemooh dan dijauhi.

Subyek merasa di lingkungannya menjadi bahan pergunjingan tetangganya. Subyek sering mendengar secara tidak langsung tentang apa yang dipergunjingkan, seperti keyakinannya yang dianggap aneh, keikutsertaan ke Kalimantan yang dianggap sebagai bentuk pelarian dari bubarnya Gafatar, dan sebagainya. Hal ini dirasakan subyek sebagai bentuk resistensi. Bagi subyek, jika memang menerima seseorang, maka segala bentuk perbedaan yang ada mestinya juga diterima dan tidak perlu lagi dipergunjingkan.

Selain bahan pergunjingan yang didengar secara tidak langsung oleh subyek, dalam perilaku keseharian masyarakat di lingkungannya juga dianggap subyek belum terbuka. Jika subyek melewati jalan kampung sementara terdapat ibu-ibu yang sedang berkumpul $2-3$ orang, ibu-ibu itu sering bisik-bisik sambil melirik subyek.

Masyarakat di sekitar subyek menyatakan bahwa mereka siap menerima subyek dan keluarganya, tetapi dengan catatan tidak membuat keresahan lagi. Keresahan yang dimaksudkan adalah penyebaran ajaran-ajaran yang dianggap sesat oleh masyarakat sekitar. Hal ini sudah terjadi sejak lama sebelum kasus Gafatar mencuat.

Menurut Kepala Desa setempat, konflik antara keluarga subyek beserta kelompoknya dengan masyarakat sekitar memang pernah 
terjadi beberapa tahun sebelumnya. Saat konflik terjadi, masyarakat mengidentifikasi subyek dan kelompoknya sebagai pengikut Qiyadah Islamiyah, kelompok yang kemudian disinyalir bermetamorfosis menjadi Gafatar. Konflik yang terjadi saat itu dapat diselesaikan dengan dimediasi oleh pemerintah desa dan kepolisian setempat.

Dengan latar belakang konflik yang pernah terjadi, ditambah dengan fenomena gafatar dan fatwa MUI tentang sesatnya gafatar semakin menguatkan keyakinan masyarakat di sekitar subyek untuk menerima dengan syarat sebagaimana dijelaskan di atas.

\section{b. Cara mengatasi resistensi yang diterima}

Menghadapi tuntutan masyarakat sekitar yang dirasakan subyek agar dirinya menjadi sama dengan mereka, subyek memilih lebih banyak diam namun cenderung menerima secara formal. Artinya, subyek sebenarnya merasa berbeda keyakinannya namun dia melakukan tindakan-tindakan seperti yang diharapkan oleh lingkungannya. Misalnya mengikuti acara pengajian di kampungnya, subyek sebenarnya merasa tidak sesuai dengan keyakinannya, namun subyek tetap mengikuti.

Dalam pergaulan sehari-hari, subyek lebih selektif dalam memilih topik pembicaraan. Subyek cenderung menghindari pembicaraan dengan topik keyakinan. Apa yang selama ini dipelajari dari kelompoknya cenderung disimpan untuk diri dan keluarganya. Selain itu, subyek juga cenderung menghindar jika ditanya orang lain tentang pengalaman hidupnya di kalimantan. Hal ini dilakukan untuk menghindari perbedaan cara pandang terhadap apa yang dilakukan di kalimantan. Jika muncul perbedaan, subyek khawatir akan menimbulkan konflik tersendiri. Apabila subyek merasa harus menyampaikan informasi tentang kehidupannya di kalimantan, subyek hanya bercerita tentang kegiatan bertani.

Cara lain yang dilakukan oleh subyek adalah dengan tetap berhubungan dengan mantan anggota gafatar lainnya. Subyek menganggap bahwa cara ini cukup efektif untuk saling menguatkan. Namun untuk berhubungan secara langsung dengan cara bertemu juga belum dapat dilakukan karena keberadaan mereka masih disibukkan dengan menata kembali kondisi ekonomi keluarga. Subyek juga menyampaikan harapannya untuk dapat beraktivitas sosial bersama kelompoknya seperti yang dulu sering dilakukan.

Dalam kesehariannya, subyek juga lebih jarang untuk berkumpul dengan tetangganya. Subyek lebih memilih beraktivitas di rumah. Subyek menilai bahwa jika sering berkumpul dengan tetangga 
tanpa keperluan yang jelas tidak memberikan manfaat apa-apa. Justru lebih sering menjadi ajang gosip. Hal seperti itulah yang dihindari oleh subyek.

\section{c. Pola penyesuaian diri}

Dari penjelasan di atas didapatkan beberapa hal yang dilakukan subyek dalam upaya penyesuaian diri adalah :

1. Mengikuti apa yang dikehendaki oleh lingkungannya terhadap dirinya, meskipun dirinya merasa tidak sesuai dengan apa yang dilakukan.

2. Lebih berhati-hati untuk berinteraksi dengan orang lain sehingga terkesan lebih menarik diri dari lingkungannya.

3. Lebih selektif dalam memilih topik pembicaraan dengan orang lain. Subyek cenderung menghindari pembicaraan dengan topik keyakinan atau hal-hal yang berkaitan dengan keagamaan.

4. Tetap berhubungan dengan mantan anggota gafatar lainnya sebagai bentuk pencarian dukungan psikologis.

\section{- $\quad$ Subyek Ketiga (S)}

Subyek ketiga berinisial S berjenis kelamin laki-laki, berusia 53 tahun dengan seorang istri dan dua anak. Subyek berasal dari Desa Tumapel Kec. Duduk Sampeyan Kabupaten Gresik. Subyek bersama istri dan kedua anaknya baru tiga hari berada di Mempawah, Kalimantan Barat. Sebelum berangkat ke kalimantan, subyek menjual rumahnya kepada saudaranya. Saat kembali ke desanya, subyek menumpang di rumah yang sudah dijualnya.

Subyek menyatakan bahwa dia pulang dari kalimantan hanya berbekal pakaian yang dikenakan saja. Semua harta yang dibawanya ikut terbakar. Karena baru tiga hari datang ke Mempawah, subyek belum sempat menggunakan uang bekalnya. Semua masih berada dalam koper yang ikut terbakar.

Meski baru tiga hari di Mempawah, subyek terkesan cukup memahami kondisi di sana. Hal ini ditunjukkan dengan cerita yang disampaikan tentang kondisi di sana. Subyek menceritakan bahwa sesampai di sana, subyek langsung bergabung dengan yang lain menggarap sawah. Sementara istrinya memasak di dapur umum bersama ibu-ibu yang lain. Sedangkan anak-anak usia sekolah juga bersekolah di lingkungan tersebut. Mereka menyediakan satu 
bangunan untuk sekolah bagi anak-anak dengan guru dari kalangan mereka sendiri yang sebelumnya memang berprofesi sebagai guru.

Subyek juga menceritakan bahwa kehadiran komunitas mereka di Mempawah sebenarnya mendapat sambutan positif dari masyarakat di lingkungan sekitar. Masyarakat justru belajar dari mereka bagaimana mengolah lahan gambut menjadi subur. Karena lahan yang mereka kerjakan dulunya adalah lahan yang terlantar dan gersang. Setelah kehadiran mereka di sana, lahan tersebut menjadi subur dan dapat ditanami berbagai tanaman pertanian. Hal ini membuat masyarakat sekitar heran dan kemudian belajar pada mereka bagaimana mengolah tanah. Berdasar apa yang diketahuinya itulah subyek merasa heran dengan peristiwa pembakaran dan pengusiran yang terjadi.

Peristiwa pembakaran itu terkesan membekas cukup dalam bagi subyek. Beberapa kali subyek menceritakan kronologis peristiwa tersebut. Subyek menyatakan bahwa peristiwa itu sengaja dilakukan dan sudah dipersiapkan secara rapi. Menurut subyek, semua penghuni di pemukiman itu sudah siap untuk meninggalkan lokasi. Semua sudah mengemas barang-barangnya dan siap diangkut dengan angkutan yang disiapkan oleh pihak pemerintah setempat. Pemerintah setempat menjanjikan mereka akan diungsikan pagi hari, namun hingga siang hari mereka belum dievakuasi hingga terjadinya pembakaran tersebut. Mereka berlarian menyelamatkan diri dan meninggalkan barang-barang yang sudah dikemas.

Selain uang 10 juta yang masih tersimpan di kopernya, dokumen-dokumen seperti identitas diri juga ikut terbakar. Subyek beserta istri dan kedua anaknya tidak memiliki apa-apa lagi.

a. Bentuk resistensi yang diterima dari lingkungan

Subyek ketiga berasal dari desa yang sama dengan subyek kedua. Sama dengan subyek kedua, subyek ketiga ini juga pernah mengalami konflik dengan masyarakat sekitar beberapa tahun sebelum munculnya persoalan gafatar. Menurut kepala desa setempat, subyek bahkan sempat diungsikan ke kantor polisi selama dua hari untuk menghindari amukan massa. Namun setelah konflik tersebut dapat didamaikan, subyek kembali dan masyarakat dapat menerima dengan syarat subyek tidak melakukan hal-hal yang dianggap meresahkan yaitu menyebarkan paham atau keyakinan yang dianggap sesat oleh lingkungannya.

Setelah dipulangkan dari kalimantan, subyek sebenarnya ragu apakah harus kembali ke desanya. Selain kebingungan tentang di 
mana akan tinggal, subyek juga khawatir kehadirannya akan menimbulkan konflik seperti yang pernah terjadi sebelumnya. Namun dirinya merasa terdesak oleh kondisi yang mengharuskan dia untuk kembali ke desanya. Subyek mengaku dirinya dan keluarganya bersiap-siap untuk menghadapi berbagai resiko yang mungkin akan terjadi. Namun setelah pulang ke desa, hal-hal yang dikhawatirkan tentang munculnya konflik tidak terjadi.

Sesampainya di rumah subyek justru didatangi tetangga sekitar untuk melihat keadaannya sebagaimana layaknya mengunjungi tetangga yang pulang dari bepergian jauh. Subyek juga dapat tinggal di rumah yang sudah dijual kepada saudaranya. Kondisi tersebut tentu dapat menguatkan diri subyek di lingkungannya.

Namun demikian, ada juga beberapa orang di lingkungannya menyampaikan pernyataan yang dianggap ejekan oleh subyek seperti, "mulane ta dadi wong ojok sing aneh-aneh, nek wis ngene iki lak soro dewe (makanya jadi orang jangan yang aneh-aneh, kalau sudah begini kan sengsara sendiri)." Selain pernyataan tersebut, sebagian besar masyarakat menyarankan agar subyek bertobat. Subyek menganggap hal itu sebagai bentuk syarat dari penerimaan masyarakat kepada dirinya.

Masyarakat di sekitar juga menyatakan bahwa mereka berharap subyek dan keluarganya kembali kepada ajaran Islam yang benar, sebagaimana yang dipraktikkan masyarakat di lingkungan tersebut. Hal ini didasarkan pada kekhawatiran mereka akan menyebarnya ajaran-ajaran seperti yang dikembangkan oleh qiyadah islamiyah atau gafatar.

Jika ajaran tersebut disebarkan, dianggap sebagai hal yang meresahkan oleh masyarakat sekitarnya. Maka masyarakat di sekitar subyek menginginkan subyek tidak menyebarkan ajaran-ajaran Islam yang pernah dipelajari di gafatar. Hal itu memang diakui oleh masyarakat sebagai syarat diperbolehkannya subyek kembali ke desanya. Karena itu, tetangga subyek sering mengajak subyek untuk ikut sholat berjamaah di musala atau masjid sekitar dengan harapan subyek tidak mengikuti kelompoknya lagi.

b. Cara mengatasi resistensi yang diterima

Subyek belum lama meninggalkan desanya. Hal ini membuat subyek tidak begitu dapat membedakan perlakuan masyarakat sekitarnya terhadap dirinya saat sebelum berangkat maupun setelah 
dia datang. Secara umum, menurut subyek masyarakat di sekitarnya bisa menerima dirinya dan keluarganya kembali.

Berbagai pernyataan yang dianggap bernada ejekan itupun tidak dihiraukannya. Subyek merespon pernyataan itu dengan tertawa untuk mencairkan suasana. Subyek juga memilih mengikuti apa yang diharapkan oleh masyarakat di lingungannya, seperti ketika diajak sholat berjamaah dan aktifitas lainnya.

Dalam interaksi dengan masyarakat sekitar, subyek masih cenderung lebih selektif dalam memilih topik pembicaraan. Subyek lebih aktif bercerita tentang aktivitas sosial dan kegiatan bertani yang dia ketahui di Kalimantan. Namun jika muncul pembicaraan dengan topik keagamaan, subyek cenderung diam, pasif, dan menjadi pendengar saja meskipun ada hal-hal yang dirasakan berbeda oleh subyek. Subyek mengaku melakukan hal itu dikarenakan subyek khawatir jika perbedaan pandangannya disampaikan, akan muncul penolakan dan sikap yang berbeda terhadap dirinya.

Sebagaimana yang dilakukan subyek satu dan dua, subyek ketiga ini juga masih berhubungan dengan mantan anggota gafatar lainnya. Meskipun subyek menyatakan belum mengetahui apa rencana hidupnya berkaitan dengan para mantan anggota gafatar lainnya, subyek tetap menunggu perkembangan berikutnya. Subyek juga menyatakan bahwa jika diberi kesempatan untuk transmigrasi, subyek akan mengikuti program tersebut bersama beberapa temannya yang juga mantan anggota gafatar. Saling keterhubungan dirinya dengan mantan anggota lainnya dirasakan subyek cukup menguatkan dirinya untuk menata kembali kehidupannya.

c. Pola penyesuaian diri

Beberapa hal yang dilakukan subyek dalam upaya penyesuaian diri adalah :

1. Cenderung mengabaikan respon negatif seperti pernyataan yang bernada mencemooh dari lingkungan, dan berusaha menetralisir keadaan.

2. Selektif dalam memilih topik pembicaraan dengan orang lain. Subyek cenderung menarik diri ketika topik pembicaraan mengarah pada persoalan keagamaan, serta mengalihkan pembicaraan tentang aktivitas sosial dan pertanian.

3. Tetap berhubungan dengan mantan anggota gafatar lainnya sebagai bentuk pencarian dukungan psikologis, serta menunggu perkembangan berikutnya yang menyangkut aktifitas kelompok (mantan anggota gafatar). 


\section{Pembahasan}

Fenomena gafatar yang muncul dengan pemberitaan massif di media massa cukup menyita perhatian publik dari semua kalangan. Meski pihak pemerintah, berbagai organisasi masyarakat maupun keagamaan menyerukan agar memperlakukan mantan anggota gafatar dengan baik, namun kemunculan resistensi di masyarakat tetap saja terjadi. Adanya fatwa sesat merupakan bentuk pelabelan negatif yang memberikan dampak negatif pula, diantaranya memunculkan bentukbentuk resistensi tertentu dari masyarakat. Ganengwin (2007), menjelaskan bahwa pemberian label negatif cenderung akan memberikan dampak negatif bagi individu yang diberi label. Dampak negatif yang dapat muncul adalah menarik diri dari lingkungannya atau bahkan dikucilkan.

Meskipun apa yang dialami ketiga subyek tidak sampai dikucilkan, tetapi penerimaan masyarakat kepada subyek disertai dengan syarat yang berupa tuntutan agar subyek mengikuti cara hidup dan keyakinan sebagaimana yang dianut oleh masyarakat di lingkungannya. Selain itu, subyek pertama masih dicurigai menyebarkan ajaran yang difatwakan sesat.

Menghadapi resistensi yang diterima, ketiga subyek memberikan respon yang berbeda. Namun ketiganya memberikan respon yang sama dalam satu hal, yaitu kecenderungan menghindari pembicaraan tentang agama dan keyakinan. Hal ini dapat diartikan bahwa ketiga subyek cenderung menuruti apa yang diinginkan masyarakat di lingkungannya, tetapi tidak mengikuti. Subyek tetap memegang teguh apa yang diyakini, namun tidak dimunculkan di lingkungannya.

Dari cara ketiga subyek dalam mengatasi resistensi yang diterima dapat diambil sebagai gambaran tentang pola penyesuaian dirinya. Terdapat dua hal yang sama dalam pola penyesuaian dari ketiga subyek, yaitu lebih selektif dalam memilih topik pembicaraan ketika berinteraksi dengan masyarakat di lingkungannya, serta tetap berhubungan dengan mantan anggota gafatar lainnya untuk saling memberikan dukungan psikologis. Kedua hal tersebut dapat diartikan bahwa dalam penyesuaian diri, ketiga subyek memilah persoalan menjadi dua, yaitu persoalan keyakinan keagamaan dan persoalan sosial.

Secara sosial, ketiga subyek dapat menyesuaikan diri dengan baik. Hal ini ditandai dengan kegiatan-kegiatan sosial yang selalu 
diikutinya, juga ditandai dengan topik pembicaraan yang dilakukan secara selektif. Ketiga subyek selalu mengarahkan pembicaraan pada topik-topik pekerjaan dan sosial. Sementara pembicaraan tentang keyakinan beragama cenderung dihindari oleh ketiga subyek. Subyek lebih memilih membicarakan keyakinan beragamanya dengan sesama mantan anggota gafatar.

Selain itu, hubungan antar sesama juga masih dijalin untuk mendapatkan dukungan psikologis. Hal ini dapat dipahami bahwa dukungan psikologis memang dibutuhkan oleh subyek agar dapat menyesuaikan diri di lingkungannya masing-masing. Menurut Schneiders (1964), menyatakan bahwa salah satu faktor yang mempengaruhi penyesuaian diri adalah keadaan psikologis. Keadaan mental yang baik merupakan syarat bagi terciptanya penyesuaian diri yang baik. Selain itu, keadaan mental yang baik akan mendorong individu untuk memberikan respon yang selaras dengan dorongan internal maupun tuntutan lingkungannya.

Dengan dukungan psikologis yang saling diberikan oleh sesama mantan anggota gafatar, maka harapan untuk dapat menyesuaikan diri dengan baik lebih terbuka.

\section{Simpulan dan Saran}

Berdasarkan hasil penelitian yang telah dijelaskan pada bab sebelumnya dapat disimpulkan bahwa terdapat beberapa bentuk resistensi yang diterima oleh mantan anggota gafatar pasca pemulangan ke daerah asal. Adapun bentuk resistensi yang diterima adalah kecurigaan akan penyebaran keyakinan yang sudah difatwakan sesat oleh MUI, pola hubungan terlalu formal dan kurang intim sebagai teman maupun tetangga, tuntutan untuk mengikuti berbagai tradisi di lingkungannya yang dianggap Islami, menjadi bahan pergunjingan, dikhawatirkan menimbulkan keresahan di lingkungan, dan cemoohan secara verbal.

Dengan resistensi yang diterima, mantan anggota gafatar mengatasinya dengan cara menghindari pembicaraan tentang keagamaan, menjelaskan aktivitas di perantauan untuk menetralisir kecurigaan, mengikuti keinginan masyarakat meski merasa tidak sesuai dengan dirinya, membatasi interaksi, dan mengabaikan cemoohan.

Pola penyesuaian diri yang dilakukan adalah lebih selektif dalam memilih topik pembicaraan untuk menghindari perbedaan, mencoba berpikir dari sudut pandang orang lain, mengikuti apa yang 
dikehendaki oleh lingkungan terhadap dirinya, menjelaskan tentang kondisi yang dialami dan berusaha memberikan alternatif cara pandang kepada lingkungannya dalam melihat dirinya, tetap berhubungan dengan mantan anggota gafatar lainnya.

Berdasarkan simpulan penelitian yang didapatkan maka dapat diajukan saran-saran sebagai berikut :

1. Bagi Mantan Anggota Gafatar

Perlu lebih terbuka dengan masyarakat sekitar dengan mencoba memahami adanya sikap yang berbeda kepada dirinya dan tidak mengedepankan sikap defence seperti membatasi diri dalam berinteraksi, sehingga lebih memungkinkan untuk menjalin interaksi lebih intim.

2. Bagi Masyarakat dan Pemerintah

Perlu menyikapi lebih bijaksana dengan adanya fatwa MUI tentang ajaran yang dikembangkan gafatar sebagai ajaran yang sesat. Hal ini dapat dilakukan dengan membuka ruang dialog yang lebih luas kepada mantan anggota gafatar untuk bertukar pikiran tentang keyakinannya.

\section{Referensi}

Apa itu Gerakan Fajar Nusantara (Gafatar). 2015. http://gafatarian.blogspot.co.id/ 2015/01/apa-itu-gerakanfajar-nusantara-gafatar.html. Diunduh pada tanggal 24 Februari 2016

Calhoun J.F dan Acocella. 1995. Psikologi Tentang Penyesuaian Dan Hubungan Kemanusiaan. Alih Bahasa: R.S. Satmoko. IKIP Semarang Press. Semarang

Desmita, 2009. Psikologi Perkembangan. Remaja Rosda Karya. Bandung

Furchan, A. 1992. Pengantar Metoda Penelitian Kualitatif. Usaha Nasional. Surabaya

Gafatar Sudah Bubar sejak 2015. 2016. http://regional.kompas.com/read/2016/01/12/14323651/.Gafata r.Sudah.Bubar.sejak.2015. Diunduh pada tanggal 24 Februari 2016

Haber, A dan Ruyon. 1984. Psychology Of Adjusment. Illinois: The Dorsey Press. Illinois 
Kartono, K. 2002. Psikologi Perkembangan. Rineka Cipta. Jakarta

Majelis Ulama Indonesia (MUI) Pusat mengeluarkan fatwa sesat bagi organisasi Gerakan Fajar Nusantara (Gafatar). 2016. http://www.bbc.com/indonesial berita_indonesia/2016/02/160202_indonesia_mui_gafatar_ses at. Diunduh pada tanggal 24 Februari 2016

Mantan Ketum Gafatar Akui, Kalimantan Daerah Tujuan Pertanian. 2016. http://radarpolitik.com/mantan-ketum-gafatar-akuikalimantan-daerah-tujuan-pertanian. Diunduh pada tanggal 24 Februari 2016

Miles, M. B. \& Huberman, M. A. 1992. Analisis Data Kualitatif, UI Press. Jakarta

Moleong, L.J. 2005. Metodologi penelitian kualitatif edisi revisi. PT Remaja Rosdakarya. Bandung

Pramadi, A. 1996. Hubungan Antara kemampuan Penyesuaian Diri Terhadap Tuntutan Tugas Dan Hasil Kerja . Jurnal Psikologi Anima. Volume. XI No. 43.

Psikolog Tika Bisono: Gafatar Adalah Fenomena Lama. 2016. http://www.gatra.com/nusantara/nasional/182096-psikologmassa-gafatar-adalah-fenomena-lama. Diunduh pada tanggal 24 Februari 2016

Ribuan Warga Bakar Permukiman Gafatar di Kalimantan Barat. 2016. http://m.liputan6.com/news/read/2415932/ribuan-wargabakar-permukiman-gafatar-di-kalimantan-

barat?\&utm_source=Digital\%20

Marketing\&utm_medium $=$ Channel $\& u t m \_$content $=$Gafatar $\% 20$ Mobile\&utm_campaign $=$ Google \& gclid $=C K-O-$ ODlissCFdeKaAodhVUEgg. Diunduh pada tanggal 24 Februari 2016

Tak Tahan Opini Publik Yang Buruk, Ormas Gafatar Nyatakan Diri Bubar. 2015. http://www.borneonews.co.id/berita/17144-taktahan-opini-publik-yang-buruk-ormas-gafatar-nyatakan-diribubar. Diunduh pada tanggal 24 Februari 2016 